Olga PRZYBYLA

Uniwersytet Śląski w Katowicach

(iD) 0000-0001-8924-3102

\title{
Trudności w czytaniu i pisaniu dzieci z zaburzeniami motorycznymi o podłożu sensorycznym, czyli uczeń z dyspraksją na lekcjach języka polskiego
}

Difficulties in Reading and Writing Experienced

by Children with Sensory-Based Motor Disorders, That Is, the Pupil with Dyspraxia in Polish Language Classes

Summary: The aim of the article is to present the problem of the functioning of the student with disorders in the development of coordination (dyspraxia) in Polish language classes. Basing on the analysis of linguistic material (the sample included selected activities in the field of Polish language education: techniques for mastering reading and writing, as well as communication skills and language skills related to the creation of oral and written speeches) and literature on the subject, problems related to reading and writing experienced by children with sensory-based motor disorders were presented. The discussed clinical trials pointed to deficits in the processing of visual and auditory stimuli in their temporal desynchronization with tactile-proprioceptivekinesthetic modalities. The problems that dyspraxics encounter in the case of speaking and reading activities result from the insufficient mastery of the auditory or visual pattern of a word, and insufficient auditory-visual-sensory-motoric memory.

Key words: dyspraxia, Polish language education, writing difficulties, difficulties in writing 
Oddziaływać mogę tylko wtedy, gdy coś chwytam, ujmuję. Gdy ujmuję otoczenie i tym samym na coś działam, zwracam się w jego stronę, spostrzegam je, biorę za prawdę.

Félicie Affolter

Deficytom w sferze sensorycznej i trudnościom w zakresie integracji sensomotorycznej towarzyszą nierzadko dysfunkcje w zakresie programowania ruchu. Nieprawidłowości związane z percepcją ruchu oraz problemy w zakresie kontroli postawy i koordynacji w przyjętej klasyfikacji chorób ICD-10 określa się mianem specyficznych zaburzeń rozwoju funkcji motorycznych. Swoim zakresem pojęcie to odnosi się do zaburzeń neurorozwojowych występujących u dzieci, które mają trudności z kontrolowaniem ruchu w następstwie słabej umiejętności jego planowania i jest określane mianem dyspraksji. Wyraz „dyspraksja” powstał z dwóch greckich słów: dys oznaczającego 'słabe' lub 'trudne' oraz praxis, czyli 'ruch', 'planowanie ruchu'². W piśmiennictwie poświęconym problemom motorycznym dzieci (z wyłączeniem dzieci z dysfunkcjami neurologicznymi, takimi jak: mózgowe porażenie dziecięce, dystrofie mięśniowe itp.) funkcjonują obok dyspraksji wymiennie dwie nazwy — zaburzenie rozwoju koordynacji (developmental coordination disorder - DCD) ${ }^{3}$ lub zespół „niezgrabnego dziecka" $(\mathrm{F} 82)^{4}$.

${ }^{1}$ F. Affolter: Spostrzeganie, rzeczywistość, język. Przeł. T. Duliński. Warszawa 1997, s. 17.

${ }^{2}$ G. Platt: Pokonać dyspraksję. Prosty program ćwiczeń poprawiajacych umiejętności ruchowe w domu $i$ w szkole. Tłum. P. Sørensen. Gdańsk 2015, s. 71.

${ }^{3}$ Zaburzenie rozwoju koordynacji, ang. developmental coordination disorder (DCD) jest nazwą stosowaną w Stanach Zjednoczonych, w Wielkiej Brytanii przyjęła się nazwa dyspraksja. W literaturze funkcjonują ponadto określenia: syndrom niezdarnego dziecka; agnozja i apraksja rozwojowa; minimalna dysfunkcja ruchowa; trudności z uczeniem się motorycznym; dysfunkcja neurorozwojowa; dysfunkcja percepcyjna/percepcyjno-motoryczna; niezręczność fizyczna; dysfunkcja sensoryczno-motoryczna. G. Platt: Pokonać dyspraksję..., s. 9.

${ }^{4}$ W Polsce - zgodnie z klasyfikacją chorób ICD-10 — obowiązuje nazwa „specyficzne zaburzenia rozwojowych funkcji motorycznych", która swym zakresem obejmuje: rozwojową dyspraksję, rozwojowe zaburzenia koordynacji, zespół „niezgrabnego dziecka” (F82). Klasyfikacja zaburzeń psychicznych i zaburzeń zachowania w ICD-10. Opisy kliniczne i wskazówki diagnostyczne. Red. przekł. S. Pużyński, J. W ciórka. Kraków—Warszawa 2007, s. 207-208. 


\section{Zaburzenia motoryczne o podłożu sensorycznym - ujęcie definicyjne}

Zaburzenia motoryczne o podłożu sensorycznym przejawiają się jako zaburzenia posturalne ${ }^{5}$ oraz dyspraksja ${ }^{6}$, którym towarzyszą słabe proprioceptywne sprzężenie zwrotne ${ }^{7}$ oraz słabe dotykowe sprzężenie zwrotne ${ }^{8}$. Współwystępują z nimi: obniżona koncentracja uwagi i ogólny brak hamowania w ośrodkowym układzie nerwowym (nadmierne pobudzenie ośrodkowego układu nerwowego, nierzadko przejawiające się jako nadmierna ruchliwość) ${ }^{9}$, brak pewności siebie

${ }^{5}$ Zaburzenia posturalne (hipotonia posturalna) odnoszą się do problemów z równowagą, statyczną i dynamiczną, i są formą nieprawidłowych zachowań ruchowych. Prawidłowe zachowania ruchowe określają bowiem właściwe odruchy postawy. Odruchy postawy stanowią grupę reakcji wpływających na rozwój postawy, zapewniają możliwość jej przyjmowania i utrzymania. W zakres odruchów postawy wchodzą: reakcje statyczne (zapewniają stałość przyjętej postawy i podtrzymują prawidłowe położenie kończyn); reakcje nastawcze (umożliwiają przyjęcie właściwej postawy po nieprawidłowym ułożeniu); reakcje równoważne (zapewniają równowagę ciała z chwilą zmiany położenia środka ciężkości). Kontrola posturalna zapewnia stabilną podstawę dla ruchu głowy, oczu, kończyn. Zob. M. Matyja: Neurorozwojowa analiza wad postawy ciała u dzieci i młodzieży. Katowice 2012.

${ }^{6}$ Zaburzenie dotyczy problemów z planowaniem, organizacją i realizacją zachowań ruchowych na wszystkich poziomach motoryki. Obejmuje trudności w koordynacji w zakresie motoryki dużej, motoryki małej oraz motoryki, np.: nieumiejętne wykonywanie ruchów naprzemiennych (aktywności związanych z przekraczaniem linii środkowej ciała) czy też kłopoty w opanowaniu umiejętności mówienia, pisania, czytania. Zob. G. Platt: Pokonać dyspraksję...; O. Przybyla: Zaburzenie rozwoju koordynacji - dyspraksja. Przeglad badań. „Logopedia Silesiana” 2016, t. 5, s. 227-248.

7 Słabe proprioceptywne sprzężenie zwrotne realizuje się w niskiej świadomości ciała oraz nieprawidłowej świadomości własnych ruchów, w tym upośledzeniu ruchów mięśni twarzy będących przyczyną zaburzeń mowy i połykania; wysokiej męczliwości mięśni i słabej stabilności stawów, co ma swoje odzwierciedlenie m.in. w obniżonej sprawności palców, dłoni i nadgarstków; nieprawidłowych ruchach gałek ocznych. Czucie głębokie (proprioceptywne) powstaje w wyniku pobudzenia receptorów narządu ruchu. Receptory te znajdują się w mięśniach, ścięgnach, torebkach stawowych i więzadłach. Czucie głębokie dzieli się na czucie mięśniowe, pochodzące od receptorów w mięśniach i ścięgnach, oraz czucie kinestetyczne (kinestezję), które łączy się z odczuwaniem ułożenia części ciała i ich ruchem, a także czuciem ciężaru i siły przeciwstawiającej się tym ruchom. Czucie głębokie stanowi źródło informacji dla ośrodków ruchowych na temat stanu narządu ruchu, jego percepcji oraz ułożenia części ciała i stereognozji. B. Sadow ski: Biologiczne mechanizmy zachowania się ludzi i zwierząt. Warszawa 2012, s. 165-166.

8 Dotyk stanowi podstawowy i pierwotny zmysł, którego największym receptorem są wrażenia zmysłowe płynące z ciała przez skórę. Dotykowa informacja sensoryczna jest ważna dla osiągnięcia mięśniowej oraz ruchowej aktywności w zakresie percepcji i jest określana mianem pasa czuciowo-ruchowego. Słabe dotykowe sprzężenie zwrotne oznacza niską wrażliwość na dotyk. Zob. V.F. Mass: Uczenie sie przez zmysty. Wprowadzenie do teorii integracji sensorycznej. Tłum. E. Grzybowska, Z. Przyrowski, M. Ślifirska. Warszawa 1998.

${ }^{9}$ Ibidem, s. 229-230. 
i niska samoocena oraz problemy interpersonalne, m.in. unikanie, wycofanie; frustracja; osamotnienie czy też przyjęcie roli klasowego błazna ${ }^{10}$.

Wyniki przeprowadzonych w ostatnich latach na świecie badań wskazują, że problem dotyka od $5 \%$ do $9 \%$ wszystkich dzieci ${ }^{11}$, przy czym zwraca się uwagę na fakt występowania dyspraksji u osób ze specyficznymi zaburzeniami rozwoju językowego, dysleksją, zespołem deficytu uwagi, zespołem nadpobudliwości psychoruchowej z deficytem uwagi oraz spektrum autyzmu. U podłoża odmiennych obrazów klinicznych występujących w wymienionych zaburzeniach leżą przede wszystkim problemy z koordynacją w złożonych aktywnościach angażujących wielomodalną integrację i wymagających szybkiego oraz precyzyjnego działania. Wszelkie bowiem przejawy opóźnień lub zaburzeń w obrębie rozwoju ruchowego, intelektualnego, społeczno-emocjonalnego oraz językowego wraz z współwystępującymi trudnościami w zakresie zdolności komunikacji znajdują uzasadnienie w nieprawidłowym przebiegu doskonalenia zdolności kontroli ruchu i funkcji wykonawczych $^{12}$.

Dlatego też na wszystkich etapach kształcenia powinno się uwzględniać poziom dojrzałości motorycznej uczniów. Na sukces szkolny ucznia wpływają bowiem — poza ogólnie dobrym stanem jego zdrowia — także jego doświadczenia ruchowe oraz stan zaawansowania dojrzałości motorycznej, gdyż: „zdolność sterowania ruchami jest związana z możliwością tworzenia umysłowych programów działania”"13. Dojrzewanie motoryczne ${ }^{14}$ określa możliwości procesu motorycznego uczenia się ${ }^{15}$, uczenie się motoryczne to zaś — jak podkreśla

${ }^{10}$ G. Platt: Pokonać dyspraksję..., s. 20.

11 J.A. Cairney et al.: Developmental coordination disorder and overweight and obesity in children aged 9-14 y. „International Journal of Obesity” 2005, No. 29, s. 369-372. Zob. także: A.L. Barnett, L. Kooistra, S.E. Henderson: „Clumsiness” as syndrome and symptom. „Human Movement Science" 1998, Vol. 17, Issues 4-5, s. 435-447; P.J. Beek \& P.C. van Wieringen: Human Movement Science. Special Issue: Developmental Coordination Disorder: „Diagnosis, description, processes and treatment" 2001, 20 (1/2), s. 7-447; Adapted Physical Activity Quarterly. Ed. S.E. Henders on. Special Issue: „Developmental. Coordination Disorder” 1994, No. 11.

${ }_{12}$ O. Przybyla: Motoryczne zdolności koordynacyjne w świetle badań nad mowa. W: Metodologia badań logopedycznych z perspektywy teorii i praktyki. Gdańsk 2015, s. 324.

${ }_{13}$ B. Czabański: Ksztatcenie psychomotoryczne. Wrocław 2000, s. 50.

${ }^{14}$ Proces dojrzewania motorycznego jest ściśle powiązany z pamięcią genetyczną i zależny przede wszystkim od tego, z czym przyszliśmy na świat (baza startowa procesu motorycznego).

15 Proces motorycznego uczenia się jest determinowany przede wszystkim przez środowisko człowieka. Stanowi średnią matematyczną: doświadczeń gatunku ludzkiego (zawarte w genach) oraz doświadczeń indywidualnych dziecka. Dlatego też ograniczenie ruchliwości młodego człowieka może znacznie ograniczyć możliwości jego motorycznego dojrzewania. Ćwiczenia wspomagają fizyczne i ruchowe dojrzewanie człowieka i umożliwiają opanowywanie wielu różnych umiejętności (stanowią okazję do uczenia się nowych czynności ruchowych). Brak zachęt do poznawania nowych czynności ruchowych może mieć ujemny wpływ na postępy uczenia się motorycznego. 
Rilo Pöhlmann ${ }^{16}$ - przede wszystkim planowanie i programowanie umysłowe. Proces uczenia się odbywa się etapami, które można ogólnie ująć jako drogę od „przyswojenia” (przez uwewnętrznienie oraz uzewnętrznienie, czyli interioryzację i eksterioryzację) aż do „zróżnicowanego zastosowania”"17.

\section{Cel i metodyka badań}

Ujęte $\mathrm{w}$ tak szerokiej perspektywie zagadnienie łączy się z celem artykułu, którym jest przedstawienie zagadnienia funkcjonowania ucznia $\mathrm{z}$ dyspraksją na lekcjach języka polskiego. Ze względu na złożony charakter objawów dyspraksji i występujących w jej zakresie trudności, podstawowe znaczenie dla skuteczności uczenia się na lekcjach języka polskiego mają zatem wyobrażenie motoryczne i antycypacja umysłowa praktycznego działania, których efektywność odzwierciedla się przede wszystkim w zakresie kompetencji i sprawności językowej określanej poziomem opanowania umiejętności mówienia, czytania oraz pisania. Przyjętą metodykę postępowania stanowi analiza i interpretacja wybranych wytworów dyspraktycznych uczniów starszych klas szkoły podstawowej oraz szkoły gimnazjalnej. Obejmuje ona badanie czynności czytania oraz pisania ${ }^{18}$. Teksty pochodzą z lat 2011 - 2017. Powstawały spontanicznie w czasie lekcji bądź były pisane na zajęciach terapeutycznych. Zarówno czytanie, jak i pisanie zalicza się do sprawności produkcyjnych języka. Są one procesami psychofizycznymi powstającymi dzięki koordynacji przekazów wielomodalnych realizowanych równocześnie bądź następczo (związków czasowych między elementami słuchowymi, wzrokowymi i ruchowymi) ${ }^{19}$. Próby kliniczne obejmują głośne czytanie oraz badania sprawdzające ocenę poziomu opanowania umiejętności pisania, a w ich zakresie wykorzystuje się próby: przepisywania, pisania ze słuchu oraz pisania twórczego tekstu ${ }^{20}$.

${ }^{16}$ R. Pöhlmann: Motorisches Lernen: psychomotorische Grundlagen der Handlungsregulation sowie Lernprozessgestaltung im Sport. Sportwissenschaft für die Praxis (t. I). Berlin 1986.

17 B. Czabański: Kształcenie psychomotoryczne..., s. 25.

${ }^{18}$ Wykaz prób klinicznych obejmujący czynności: mówienia, pisania i czytania wraz z materiałem egzemplifikacyjnym został zaprezentowany w artykule: O. Przybyla: Studium przypadku dziecka z zaburzeniami motorycznymi o podłożu sensorycznym. „Logopedia Silesiana” 2016, t. 5, s. $357-399$.

19 Z. Lorenc, T. Wróbel: Nauka czytania i pisania. W: Praca nauczyciela i ucznia w klasach 1-3. Red. M. Lelonek, T. Wróbel. Warszawa 1990, s. 196-197.

${ }^{20}$ Głośne czytanie umożliwia sprawdzenie rozumienia odczytywanych treści. Podobnie wybrane próby pisania zostały dobrane tak, by na ich podstawie dokonać oceny poziomu opanowania umiejętności. Aktywności weryfikowane w próbach pisania z pamięci słuchowej i pisania z pa- 


\section{Materiał badawczy}

W pracy z uczniem dyspraktycznym na lekcji języka polskiego na pierwszy rzut oka nauczyciel dostrzega nieprawidłową kontrolę postawy i koordynacji, które bezpośrednio ujawniają zaburzenia propriocepcji oraz kinestezji, m.in. nieprawidłowości w zakresie wykonywania ruchów i niskich umiejętności w zakresie motoryki małej oraz motoryki dużej ${ }^{21}$. Nierzadko uczniowie przejawiają trudności w zorganizowaniu miejsca pracy (niewłaściwe wyposażenie, nieumiejętne korzystanie z przyborów szkolnych, nieporadne planowanie aktywności, zdezorganizowanie) oraz w dostosowaniu się do nowych sytuacji. Towarzyszą im niedojrzałe zachowania i niskie umiejętności interpersonalne (nieumiejętność pracy w grupie, tendencja do wycofywania, niska przerzutność uwagi, zbyt wysoki próg pobudzenia, kłopoty z planowaniem i dostosowaniem się do otoczenia itp.). Problemy te są związane m.in. z większą zmiennością w synchronizacji i sile skurczów mięśni, dysharmonii w ruchach zarówno rytmicznych, jak i płynnych ${ }^{22}$, co znajduje odzwierciedlenie nie tylko w relacjach

mięci wzrokowej zostają objęte oceną w próbie pisania ze słuchu oraz w próbie tworzenia tekstu twórczego, gdyż wymagają właściwego przetwarzania i scalania bodźców płynących z modalności wzrokowej, proprioceptywnej, słuchowej i kinestetycznej, założeniem jest bowiem przedstawienie wieloaspektowości w funkcjonowaniu ucznia dyspraktycznego na lekcjach języka polskiego w odniesieniu do najczęstszych trudności występujących w tym zakresie.

${ }^{21}$ J.P. Wann, M. Mon-Williams, K. Rushton: Postural control and co-ordination disorders: The swinging room revisited. „Human Movement Science” 1998, Vol. 17, Issues 4-5, s. 491-514; H.G. Williams, M. Woollacott: Characteristics of neuromuscular responses underlying posture control in clumsy children. „Motor Development: Research and Reviews” 1997, Vol. 1, s. 8-23; A.J. Raynor: Strength power, and coactivation in children with developmental coordination disorder. „Developmental Medicine and Child Neurology” 2001, Vol. 43, Issue 10, s. $676-684$.

${ }^{22}$ R.H. Geuze, A.F. Kalverboer: Inconsistency and adaptation in timing of clumsy children. „Journal of Human Movement Studies” 1987, Vol. 13, Issue 8, s. 421 -432; Iidem: Tapping a rhythm: A problem of timing for children who are clumsy and dyslexic. „Adapted Physical Activity Quarterly" 1994, Vol. 11, Issue 2, s. 203-213; L. Lundy-Ekman et al.: Timing and force control deficits in clumsy children. „Journal of Cognitive Neuroscience” 1991, Vol. 3, No. 4, s. 367-376; H.E. Parker et al.: Are motor timing problems subgroup specific in children with developmental coordination disorder?. „Australian Educational and Development Psychologist” 1997, Vol. 14, Issue 1, s. 35-42; J.P. Piek, R.A. Skinner: Timing and force control during a sequential tapping task in children with and without motor coordination problems. „Journal of the International Neuropsychology Society" 1999, Vol. 5, Issue 4, s. 320-329; M.J.M. Volman, R.H. Geuze: Stability of rhythmic finger movements in children with a Developmental Coordination Disorder. „Motor Control” 1998, Vol. 2, Issue 1, s. 34-60; Iidem: Relative phase stability of bimanual and visuomanual rhythmic coordination patterns in children with a developmental coordination disorder. „Human Movement Science” 1998, Vol. 17, Issues 4-5, s. 541-572; H.G. Williams, A. Castro: Timing and force characteristics of muscle activity: Postural control in children with and without developmental coordination disorders. „Australian Educational 
interpersonalnych, lecz także w opanowaniu mówienia, pisania oraz czytania. Trudności w zakresie czytania i pisania łączą również współwystępujące w dyspraksji zaburzenia w integracji wzrokowo-motorycznej, mające związek $\mathrm{z}$ deficytem $\mathrm{w}$ odwzorowywaniu informacji wzrokowej i kinestetyczno-proprioceptywnej (trudności w określaniu rozmiaru obiektu, lokalizowaniu położenia obiektu w przestrzeni), czy kwestie wynikające z obniżenia zdolności uwagi wzrokowej ${ }^{23}$.

W celu przedstawienia zakresu trudności występujących u uczniów z dyspraksją wybrano dwa przykłady próby głośnego czytania. Realizacja jednego z nich została odnotowana na wtórniku, który w odpowiedni sposób umożliwia zaznaczenie poszczególnych elementów strukturalnych procesu czytania ${ }^{24}$. Próby głośnego czytania umożliwiają ocenę następujących elementów: techni-

and Developmental Psychologist" 1997, Vol. 14, Issue 1, s. 43-54; H.G. Williams et al.: Timing and motor control in clumsy children. „Journal of Motor Behavior” 1992, Vol. 24, Issue 2, s. $165-172$.

${ }^{23} \mathrm{R}$. Coleman et al.: Kinaesthetic acuity in preprimary children at risk of developmental coordination disorder. „, Australian Educational and Developmental Psychologist” 1997, Vol. 14, Issue 1, s. 80-86; J.I. Laszlo et al.: Clumsiness or perceptuo-motor dysfunction?. In: Cognition and action in skilled behaviour. Eds. A.M. Colley, J.R. Beech. Amsterdam 1988, s. 293-310; J.I. Laszlo et al.: Process oriented assessment and treatment of children with developmental coordination disorder. „Corpus Psyche et Societas” 1996, No. 3, s. 11-18; M. Mon-Williams: Ophthalmic factors in developmental coordination disorder. „Adapted Physical Activity Quarterly" 1994, Vol. 11, Issue 2, s. 170-178; M. Mon-Williams et al.: Visual-proprioceptive mapping in developmental coordination disorder. „Developmental Medicine and Child Neurology” 1999, Vol. 41, Issue 4, s. 247-254; J.P. Piek et al.: Motor coordination and kinaesthesis in boys with attention deficit-hyperactivity disorder. „Developmental Medicine and Child Neurology” 1999, Vol. 41, Issue 3, s. 159-165; H. Sigmundsson et al.: Inter-and intra-sensory modality matching in children with hand - eye co-ordination problems. „Experimental Brain Research” 1997, Vol. 114, Issue 3, s. 492-499; H. Sigmundsson: Inter-modal matching and bi-manual co-ordination in children with hand-eye co-ordination problems. „Nordisk Fysioterapi” 1999, No. 3, s. 55-64.

${ }_{24}$ Za: E. Górniewicz: Pedagogiczna diagnoza specyficznych trudności w czytaniu i pisaniu. Toruń 1998, s. 35-39:

- ( _ l linią ciągłą podkreśla się płynnie i poprawnie przeczytany fragment tekstu lub w przypadku całościowego czytania oderwanych wyrazów;

_ ( _ _ $)$ kreską przerywaną podkreśla się każdą sylabę, kiedy dziecko sylabizuje;

- (. . k kropkami zaznacza się wyrazy głoskowane przez dziecko;

- (._._._ zmiany technik czytania.

Zatem każdy wyraz podkreślony linią ciągłą jest poprawnie odczytany. Podkreśla się tak te wyrazy, które uczeń poprawnie odczytał i w których dokonał poprawnej syntezy. Wyrazy niepoprawnie odczytane przekreśla się, a zniekształcone - nadpisuje.

- (? ?) opuszczenie wyrazu lub liniatury zaznacza się strzałką (pozioma — nad opuszczonym wyrazem, pionowa - przy opuszczonym wierszu);

— (?|_) pomyłki w kolejności odczytywania wyrazów — między zamienionymi wyrazami;

- (| ) dłuższe przerwy między wyrazami — pionowa kreska między wyrazami. 
ki czytania, tempa czytania, identyfikacji i interpretacji popełnianych podczas czytania błędów oraz ocenę stopnia zrozumienia tekstu.

Materiał zaprezentowany do czytania stanowił pewną całość i nie był wcześniej znany osobie badanej. Do oceny czytania w pierwszym przykładzie wykorzystano tekst opracowany na podstawie podręcznika, odpowiednio dostosowany do potrzeb osoby badanej, dziesięcioletniej Justyny.

Tekst do głośnego czytania wykorzystany w próbie:

\section{Dzień Dziecka}

Nadszedł w końcu Dzień Dziecka. Wiedzieliśmy, że czeka nas coś niezwykłego, jak tylko weszliśmy do klasy. Stoliki stały pod ścianami, a krzesła na środku sali, przodem do tablicy. Pani Róża zadzwoniła mosiężnym dzwonkiem, byśmy się uciszyli. Po chwili do sali weszli aktorzy. Kogo tam nie było: siwy dziadek z długą brodą, pierzasta kura z dużym brzuchem, bociek $\mathrm{z}$ długaśnym dziobem, żabka $\mathrm{w}$ zielonych rajstopach. Domyśliliśmy się, że pokażą nam „Rzepkę” Tuwima. Piotrek zaczął marudzić, że to wiersz dla małych dzieci, ale przestał, gdy tylko zaczęło się przedstawienie. Aktorzy byli tacy zabawni! Pod koniec, kiedy wszyscy na siebie poupadali, dziadkowi nagle odpadła broda i okazało się, że to tata Piotrka! Dopiero wtedy zrozumieliśmy, że aktorami są nasi rodzice! Mieliśmy masę zabawy, kiedy próbowaliśmy odgadnąć, kto kogo zagrał. Po przedstawieniu pani przyniosła ciasto i owoce. Piotrek wziął wielki kawał sernika i patrząc na swojego tatę, powiedział, że nikt chyba nie miał tak fantastycznego Dnia Dziecka jak nasza klasa! $!^{25}$

Sposób realizacji umiejętności głośnego czytania tekstu przez dziewczynkę został przedstawiony na wtórniku:

Nadeszla dzieci dzieci Wiedziel na niezwykly

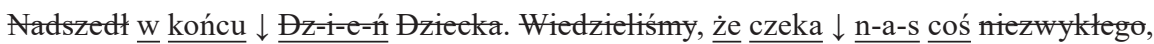

Stali stal szet ośrodku

$\underline{\text { jak tylko }}$ | w-e-sz-l-i-ś-m-y do klasy. Stoliki | stały pod ścia-na-mi, a krzesła na środku

możemy

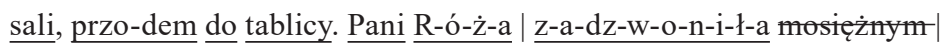

dz-w-o-n-k-i-e-m, byśmy się u-c-i-sz-y-1-i. Po chwili do s-a-l-i w-e-sz-l-i a-k-t-o-rz-y.

dugą pierzata

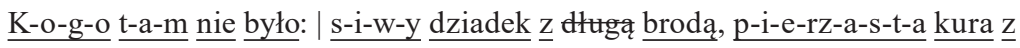

dlugością

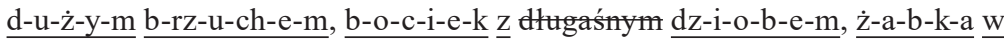

${ }^{25}$ Opracowanie własne na podstawie: M. Piotrowska, M. Szymańska: Nowe już w szkole. Warszawa 2009. 
$\longrightarrow \quad$ pokażę

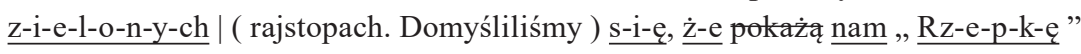

Tuwimy

ale maly

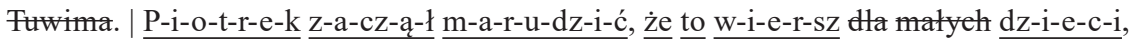

dla przestała

zaczela

ale przestat, g-d-y t-y-l-k-o zaezęło s-i-ę p-rz-e-d-s-t-a-w-i-e-n-i-e. A-k-t-o-rz-y byli tacy zabawni!

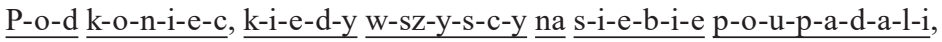

dziadek

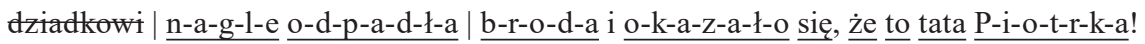

Popiera $\quad$ aktor $\rightarrow$ się

Đopiero w-t-e-d-y z-r-o-z-u-m-i-e-l-i-ś-m-y, że aktorami są | ( nasi rodzice! )

mocną próbowalimy odgadnie

M-i-e-1-i-ś-m-y asę z-a-b-a-w-y, k-i-e-d-y próbowaliśny odgadnąé k-t-o k-o-g-o

przedstawieniem $\longrightarrow$ owoc

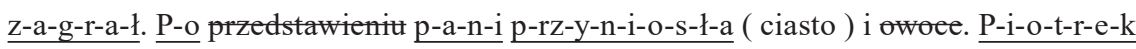

kawalek serniku patrzal

w-z-i-ą-1 w-i-e-1-k-i kawal sernika i patrząe na s-w-o-j-e-g-o t-a-t-e, p-o-w-i-e-dz-i-a-t,

się

fantastyczne

jest nasze klasy

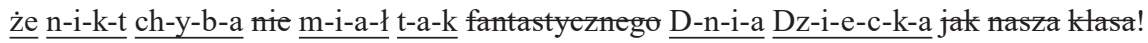

Justyna czyta bardzo cicho, tempo czytania jest bardzo wolne. Przeczytała poprawnie 114 na 155 wyrazów. Uczennica czyta w tempie ok. 15 wyrazów na minutę. Czyta, głoskując z syntezą. Opuszcza litery w wyrazach, zastępując je innymi literami lub stosuje wyrazy o innym znaczeniu. Zdarza się, że opuszcza również wyrazy w tekście. W tabeli 1 przedstawiono wyniki badania czynności czytania.

Tabela 1

Wynik badania: czytanie

\begin{tabular}{|l|l|}
\hline \multicolumn{1}{|c|}{ Typ błędu } & \multicolumn{1}{c|}{ Przykłady } \\
\hline $\begin{array}{l}\text { Zastępowanie wyrazu, } \\
\text { zmiana odczytania wyrazu }\end{array}$ & $\begin{array}{l}\text { dzieci (dzień), wiedzieli (wiedzieliśmy), na osób (na coś), nie- } \\
\text { zwykły (niezwykłego), stali (stoliki), stał (stały), szet (krzesła), } \\
\text { ośrodku (na środku), możemy (mosiężnym), długościa (z dłu- } \\
\text { gaśnym), pokaże (pokażą), Tuwimy (Tuwima), ale mały (dla } \\
\text { małych), dla przestała (ale przestał), zaczeła (zaczęło), dziadek } \\
\text { (dziadkowi), popiera (dopiero), aktor (aktorami), moca (masę), } \\
\text { próbowalimy (próbowaliśmy), odgadná́ (odgadnie), przedsta- } \\
\text { wieniem (przedstawieniu), kawałek serniku (kawał sernika), } \\
\text { patrzał (patrząc), się (nie), fantastyczne (fantastycznego), jest } \\
\text { nasze klasy (jak nasza klasa) }\end{array}$ \\
\hline Opuszczanie & dzieci (dzień), na (nas) \\
\hline $\begin{array}{l}\text { Uproszczenie grup spółgłos- } \\
\text { kowych }\end{array}$ & duga (długą), pierzata (pierzasta) \\
\hline
\end{tabular}

Źródło: Opracowanie własne. 
Sposób realizacji umiejętności głośnego czytania tekstu przez Justynę odzwierciedla niski poziomu konsolidacji bodźców wszystkich modalności, czego wyrazem są popełniane przez nią typy błędów.

Z kolei Maciej, uczeń szóstej klasy, ze stwierdzoną osłabioną zdolnością analizy i syntezy wzrokowej, uczenia się wzrokowo-ruchowego oraz obniżoną pamięcią wzrokową i pamięcią słuchową krótkotrwałą, czytał głośno następujący tekst:

\section{Wędrowiec}

Promienie słońca rozchodziły się tu, po tym przepięknym terenie i gładziły twarz odpoczywającego wędrowca. Panowała naturalna równowaga tak charakterystyczna dla nieogarnionego świata przyrody. Dźwięczała wokół puszcza, pachniała rozbujała roślinność. Źródło szemrało w pobliżu. Czyżyki ćwierkały niemiłosiernie. Mysikróliki przemykały przez widły. Gdzieś w oddali czerniły się jagody wielkości czereśni. Pachniała ziemia zryta nocą przez dziki poszukujące pędraków. Wilgoć o zapachu paproci unosiła się w powietrzu. Wiatr przywiał ją znad trzęsawiska. Muchomory czerwieniły się w wybujałej trawie. Podgrzybki maskowały się wśród igliwia. Te wszystkie wrażenia chłonął zdrożony człowiek jak energię potrzebną do dalszej wędrówki.

Próba czytania obejmowała jeden dłuższy tekst o średnim stopniu trudności, zgodny z zainteresowaniami chłopca. Czytanie miało bardzo nieregularny przebieg. Niektóre fragmenty odczytane zostały stosunkowo płynnie i bezbłędnie, ich rozmieszczenie w obrębie całości tekstu zdawało się nie mieć większego znaczenia; przy czytaniu innych Maciek głoskował szeptem i dokonywał syntezy przegłoskowanych słów, nienaturalnie wydłużał samogłoski albo się zatrzymywał. Robił długie, nawet siedmiosekundowe przerwy, intonacja i rytm były niezgodne z interpunkcją. Miało miejsce opuszczanie i zamiana całych wyrazów (tam zamiast tu; terenie zamiast terytorium; roślinność zamiast rosty; ani zamiast $a$ ), jeden raz zdarzyło się opuścić wers. Chłopiec opuszczał także litery w wyrazach (widly zamiast wiodty; mysikrólki zamiast mysikróliki). Zmiana końcówki pociągała za sobą zmianę formy kolejnych wyrazów i zakłócenie płynności spowodowane dostrzeżeniem przez czytającego błędów (panował naturalny równowaga). Czytanie zakłócało także częste powtarzanie początku słowa. Tekst globalnie został zrozumiany. Jednak podanie bliższych szczegółów nastręczało chłopcu trudności. Widoczne było przytłoczenie Maćka stanem swojej umiejętności czytania. Problemem było znaczące wydłużenie czasu czytania i konieczność wkładania w ten proces ogromnego wysiłku, co nie sprzyjało swobodnemu podążaniu za treścią. Czytanie zadanego fragmentu powinno było trwać ok. półtorej minuty, Maciek czytał go natomiast przez cztery minuty. Chłopiec próbował sobie radzić z czytaniem, głoskując, co jakiś czas 
przeplatał swoją aktywność naprzemiennie z czytaniem globalnym słów, podczas którego dochodziło do popełniania licznych błędów, spowodowanych być może całkowitym przestawianiem się w danym momencie na strategię lingwistyczną i zaniechiwaniem strategii sensorycznej. Obserwując chłopca, można było odnieść wrażenie, że mechanizm wizualny dekodowania nie idzie w parze $\mathrm{z}$ fonologicznym, podczas gdy do otwarcia „umysłowego leksykonu znaczeń” 26 potrzebne są obydwa mechanizmy równocześnie. Występujące trudności realizacyjne potwierdzają więc nieprawidłowości w zakresie przekazu międzypółkulowego i zaburzenia rozwoju koordynacji.

Dalsza analiza złożonych czynności angażujących narządy wykonawcze i układ odbiorczy w kontekście stopnia zaawansowania ich koordynacji obejmowała badanie umiejętności pisania. Pierwsze oceniane próby stanowią realizacje tekstów pisanych ze słuchu. Próba polegała na zapisaniu na kartce tekstu dyktowanego przez badającego:

Mroźna zima minęła. Zbliża się wiosna. Słońce świeci coraz wyżej nad ziemią. Z każdym dniem jest coraz cieplej. Widno jest do późna. Noce są krótkie. I nam jest już raźniej i weselej.

\section{Wynik badania: pisanie ze słuchu}

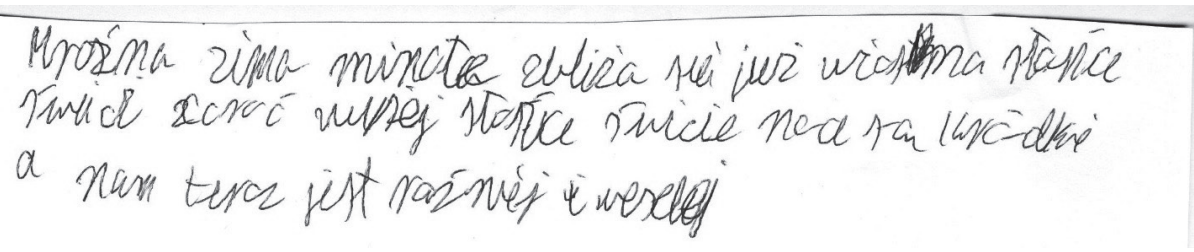

Źródło: Materiały własne.

Na wstępie został odczytany tekst dyktanda, a następnie rozpoczęto dyktowanie zdania po zdaniu. Każde zdanie dzielono na frazy, by możliwe stało się ich zapisanie. Adam (uczeń czwartej klasy), ze względu na nieutrwalony wzorzec słuchowo-wzrokowo-czuciowo-ruchowy wyrazów w zdaniach, ma trudności z zapamiętaniem porządku wyrazów w dyktowanym tekście i wydzielaniem poszczególnych zdań. Realizację chłopca stanowi jednozdaniowa wypowiedź: Mroźna zima minołe zbliża sięjuż wiosna słońce świeci coraz wyżej słońce świeci noce sa kródkie a nam teraz jest raźnej i weselej. Potwierdzeniem trudności jest również powtórzenie w obrębie zdania frazy słońce świeci. Problemy sensoryczne o podłożu motorycznym można dostrzec także w poziomie graficznym pisma. Chłopiec ma trudności w czuciowo-ruchowym zapamiętaniu kształ-

\footnotetext{
${ }^{26}$ Zob. E. Górniewicz: Pedagogiczna diagnoza specyficznych trudności w czytaniu..., s. 38.
} 
tów liter. Pisząc, myli litery: minote, ewentualnie koryguje poprawny ich zapis $\mathrm{w}$ trakcie aktywności pisania: wiosna pisana przez $m$, a następnie poprawiona. Adam ma dużą trudność w szybkim przekładaniu obrazów słuchowych tekstów na wzrokowo-czuciowo-ruchowe ich realizacje.

Podobnie kształtuje się sytuacja wykonania próby przez Daniela (również ucznia czwartej klasy).

Wynik badania: pisanie ze słuchu

Ilustracja 2

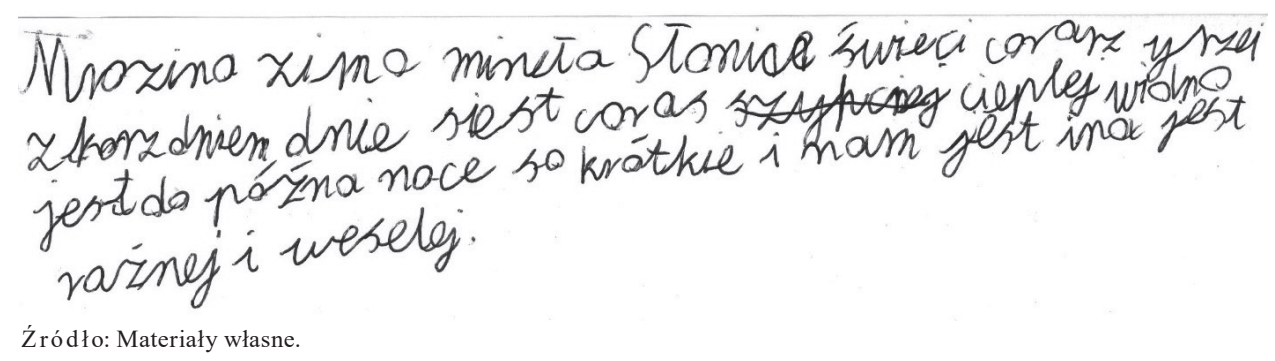

Uczeń miał duże trudności w zakresie sprawności motorycznej, na co wskazuje poziom graficzny pisma. Chłopiec w trakcie pisania przyjął nieprawidłową postawę ciała — siedział z głową nisko pochyloną w dół, prawie leżąc na ławce, trzymając pióro nieco skośnie (i dlatego przechylał się w bok). Nierzadko przechylenie w bok związane jest z potrzebą dostrzeżenia szczytu narzędzia pisarskiego, które źle trzymane, np. przez zasłanianie kciukiem jego końca, uniemożliwia widzenie obuoczne. W trakcie przepisywania można dostrzec duży wysiłek wkładany w wykonywaną czynność celem jak najdokładniejszego odwzorowania słuchanego tekstu.

Uczniowie z rozwojowymi zaburzeniami koordynacji dłużej i z większym wysiłkiem nabywają technikę pisania oraz sprawność czytania. W związku z występującymi zaburzeniami posturalnymi cechują ich nieprawidłowe reakcje nastawcze i równoważne, które przekładają się na niezdolność do planowania ruchu. Współwystępujące słabe proprioceptywne sprzężenie zwrotne łączy się z nieprawidłową świadomością własnych ruchów (m.in. konieczność kontrolowania wzrokiem narzędzia pisarskiego ogranicza dynamikę ruchów) i zwiększoną męczliwością mięśni oraz słabą stabilnością stawów, co ma swoje odzwierciedlenie w obniżonej sprawności palców, dłoni i nadgarstków oraz nieprawidłowych ruchach gałek ocznych. Czytanie oraz pisanie są dla dziecka równoczesnym wysiłkiem intelektualnym i ruchowym integrującym wielomodalne bodźce. W pisaniu są scalane z sobą takie elementy, jak: ,słuchowe wydzielanie głoski, znalezienie jej odpowiednika literowego, zapamiętanie kształtu litery oraz kolejne rozmieszczenie liter w wyrazie, napisanie litery lub wyrazu, a więc szeregu ruchów wykonanych przez różne części aparatu ruchowego ręki pod kierownic- 
twem kory mózgowej”27, dlatego też tak ważna jest obserwacja uczniów w zakresie opanowywania poszczególnych sprawności. Informacje sensoryczne są dosłownie i w przenośni oczami systemu motorycznego, zapewniają mu ,wiedzę” o tym, co on sam robi ${ }^{28}$. Doświadczenia uczniów wskazują, że proces ma charakter długotrwały. Trudności w zakresie pisania występują bowiem u uczniów w każdym wieku, co potwierdza przykład realizacji Artura, ucznia klasy szóstej. Zadaniem chłopca było napisanie następującego tekstu:

\section{Sosna zwyczajna}

Składnikiem wielu lasów jest sosna zwyczajna. Drzewo to sadzi się także na nieużytkach. Ma bardzo dobrze rozwinięty system korzeniowy, który składa się z korzenia głównego i mnóstwa korzeni pobocznych. Grzybiarz wędrujący po lesie sosnowym czy mieszanym z pewnością pamięta, że korzenie sosny współżyją z grzybnią wielu grzybów. Pod sosną śmiało możesz szukać borowików czy też kurek. Twój koszyk będzie nimi chyba napełniony po brzegi. Podziwiając sosnę zwyczajną możesz zauważyć, że ma ona przeważnie prosty pień. Może mieć kilkanaście metrów wysokości.

Wynik badania: pisanie ze słuchu

Ilustracja 3

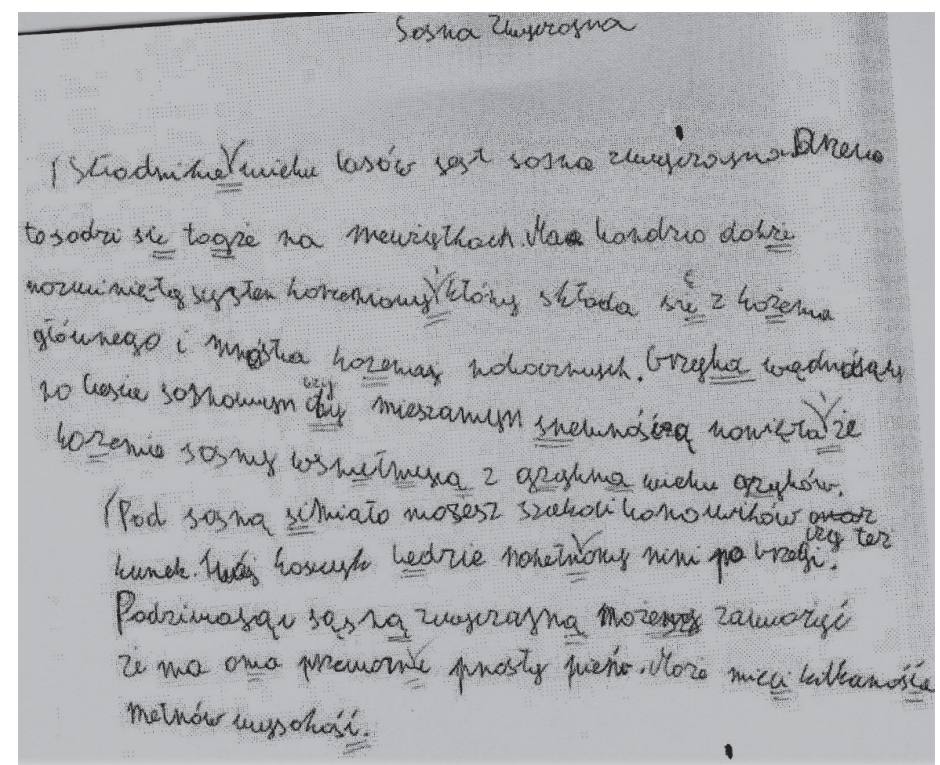

Źródło: Materiały własne.

${ }^{27}$ T. Wróbel: Pismo i pisanie w nauczaniu początkowym. Warszawa 1985, s. 50-51.

${ }^{28}$ G. Hickok: Mit neuronów lustrzanych. Rzetelna neuronauka komunikacji i poznania.

Tłum. K. Cipora, A. Machniak. Kraków 2016, s. 224. 
Podczas pisania Artur popełnia liczne błędy ortograficzne nawet w krótkich i często używanych wyrazach (dobże; kożenia; wsputrzyia zamiast wspótżyja). Pomija litery, szczególnie na końcu wyrazów (sktadnikie zamiast składnikiem; grzybia zamiast grzybiarz), używa zapisów zredukowanych graficznie - często brakuje fragmentów liter, kropek, kresek oraz znaków interpunkcyjnych, litera $m$ zamieniana jest na $n$ oraz odwrotnie (oma zamiast ona; nini zamiast nimi; kozemie zamiast korzenie), a na o i odwrotnie, liczne są też inne błędy dysymilacji (sąsną zamiast sosna). Litera $t$ wygląda często jak $t$. Głoski miękkie zamieniane są na zmiękczone i odwrotnie lub brak jest zmiękczenia ( $g z y b n a$ zamiast grzybnia; przewozne zamiast przeważnie; wysokość zamiast wysokości; nopetnony zamiast napetniony; mieci zamiast mieć; kilkanaśće; simiało zamiast śmiało; spewnośća zamiast z pewnościa). Wydaje się, że ani myśl, ani ręka nie podążają za słowem. Niektóre słowa są tak zniekształcone, że odczytanie ich umożliwia tylko porównanie z pierwowzorem tekstu. Wykonanie zadania przez Artura wskazuje na desynchronizację bodźców słuchowo-wzrokowo-czuciowo-kinestetycznych. Mylenie liter o podobnym kształcie wskazuje na obniżony poziom percepcji czuciowo-ruchowej kształtów i współwystępujących trudnościach we wzrokowym ich zapamiętaniu ${ }^{29}$. Opuszczanie liter i końcówek świadczy o stosowaniu wizualnej strategii pisania, polegającej na przywoływaniu wyrazu zapamiętanego w całości ${ }^{30}$. Nieprawidłowa realizacja zmiękczeń, zapis fonetycznie zgodny głosek zapisywanych jako bezdźwięczne (tagże) czy zaniedbywanie interpunkcji wskazują na zaburzenia uwagi i pamięci wzrokowej ${ }^{31}$. Prawidłowemu utrwalaniu wzorców pisowni nie sprzyja niski poziom przetwarzania bodźców słuchowo-czuciowo-kinestetycznych. Chłopiec podczas przepisywania tekstu z kartki popełnia błędy tej samej kategorii. Liczba błędów podczas przepisywania także nie zmniejsza się w zauważalny sposób. Dla porównania zostaje zamieszczony fragment przepisanego tekstu oraz jego pierwowzór:

Tekst do przepisania:

Wędrowiec (wersja skrócona)

Promienie słońca gładziły twarz odpoczywającego wędrowca. Dźwięczała wokół puszcza. Źródło szemrało w pobliżu. Czyżyki ćwierkały niemiłosiernie. Czerniły się jagody wielkości czereśni. Pachniała ziemia zryta nocą przez dziki poszukujące pędraków. Wilgoć o zapachu paproci unosiła się w powietrzu. Wiatr przywiał ją znad trzęsawiska.

\footnotetext{
${ }^{29}$ Ibidem, s. 46.

${ }^{30}$ E. Górniewicz: Pedagogiczna diagnoza specyficznych trudności w czytaniu..., s. 47.

${ }^{31}$ Ibidem, s. 48.
} 
Wynik badania: przepisywanie

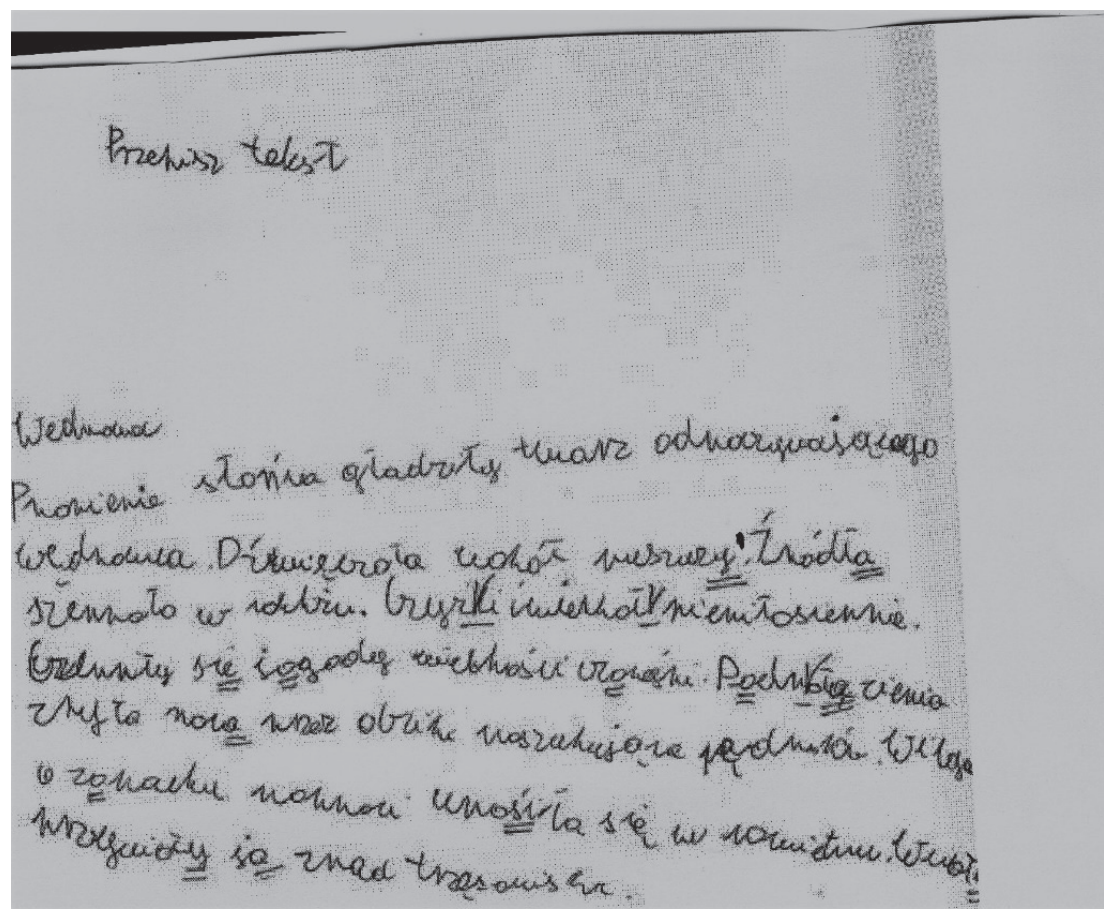

Źródło: Materiały własne.

Podczas przepisywania można dostrzec duży wysiłek wkładany w tę czynność w celu jak najdokładniejszego odwzorowania tekstu. Chłopiec bardzo często spoglądał na wzór, co świadczy o chęci dokładnego odtworzenia wzorca i współwystępujących w trakcie pisania zaburzeniach w zakresie koordynacji bodźców wzrokowo-czuciowo-kinestetycznych oraz nieprawidłowościach percepcji wzrokowej i pamięci wzrokowej świeżej. Mimo mobilizacji czynność przepisywania przebiegała powoli, jak u dziecka, które dopiero zaczęło ją opanowywać. Celem próby przepisywania jest ocena percepcji wzrokowej, m.in. w zakresie organizacji przestrzennej, oraz sprawdzenie zdolności transponowania statycznych obrazów wzrokowych pisma na system ruchów graficznych (opanowania właściwych wzorów ruchowych; ocenia się kierunek oraz kolejność kreślenia liter i ich elementów składowych, sposób łączenia liter w wyrazach). Podstawą pamięci ruchu jest opanowanie właściwej formy liter, wykształcenie sprawności prawidłowego ich łączenia w strukturze wyrazu, stabilność płynności ruchu (nieoderwane od siebie litery) determinowana odpowiednim naciskiem narzędzia pisarskiego (właściwa kontrola proprioceptywno-kinestetyczna, której towarzyszy autokontrola słuchowa). 
Problemy w zakresie zaburzeń rozwoju koordynacji przybierają nierzadko bardzo intensywny charakter, czego przykładem mogą być prace dwóch chłopców, uczniów gimnazjum. Poziom graficzny pisma Błażeja jest wyjątkowo kiepski. Oto fragment jego kartkówki:

\section{Wynik badania: tekst pisany — kartkówka}

Ilustracja 5

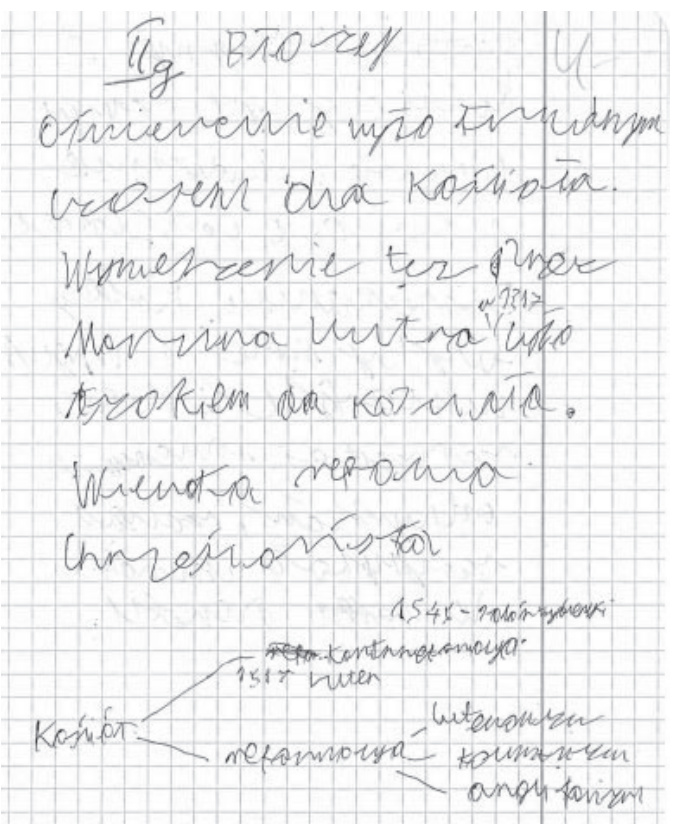

Źródło: Materiały własne.

Pismo Błażeja można z trudnością rozszyfrować dopiero po globalnym uchwyceniu sensu. Nawet odszukanie błędów w tekście nie jest łatwym zadaniem, ponieważ niemożliwe bywa ustalenie granicy między literami. Jego trudności z czytelnym pisaniem zdają się wynikać z zaburzeń koordynacji ruchowej. Ruchy ręki podczas pisania są zamaszyste i nieregularne.

Zbliżony poziom realizacji pisanego tekstu reprezentuje Marek.

Ostatnią testowaną umiejętnością uczniów dyspraktycznych było pisanie tekstu twórczego. Próba polegała na umiejętności tworzenia tekstu — opisu obrazka. Osoba badana była proszona o opisanie ilustracji. Zadanie pozwala ocenić umiejętności tworzenia tekstu pod względem poprawności formalno-językowej i stylistycznej.

Jedenastoletnia dziewczynka, Kamila, poproszona o opisanie obrazka, nie wyraziła zainteresowania zadaniem. Napisała zaledwie kilka zdań. Struktura tekstu jest mocno ograniczona. 
Wynik badania: tekst z zeszytu do informatyki

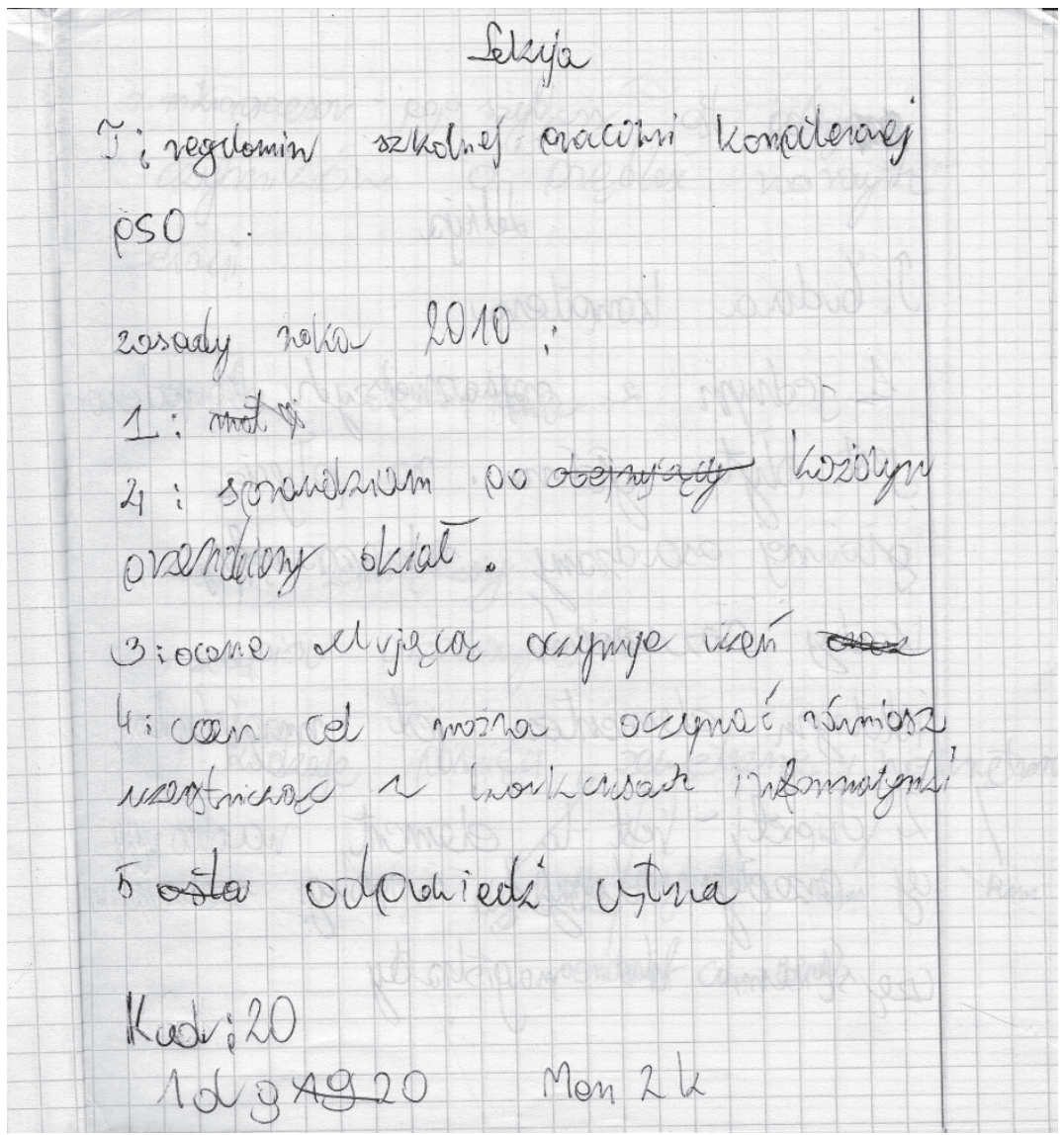

Źródło: Materiały własne.

Umiejętność tworzenia własnego tekstu pod względem poprawności formalno-językowej i stylistycznej została zrealizowana na niskim poziomie. Dziewczynka dokonała generalizacji: Na obrazku jest babcia i chłopiec, lecz nie uwzględniła w swojej wypowiedzi innych, możliwych do uwzględnienia treści. W opisie Kamili nie występują charakterystyczne dla formy wypowiedzi umiejętności gospodarowania przestrzenią w czasie „tu i teraz”. Reprezentatywność zdarzeń została ograniczona do bezwzględnego minimum: Babcia ma talesz $i$ daje zupe. Chtopiec trzyma tyszke.

Próby badania opanowania czynności pisania wskazują wyraźnie zależności pomiędzy poziomem dojrzewania procesów mózgowych i rozwojem umiejętności graficznych sprawności realizacyjnych mowy. Uczniowie dyspraktyczni wyka- 


\section{Wynik badania: pisanie tekstu twórczego}

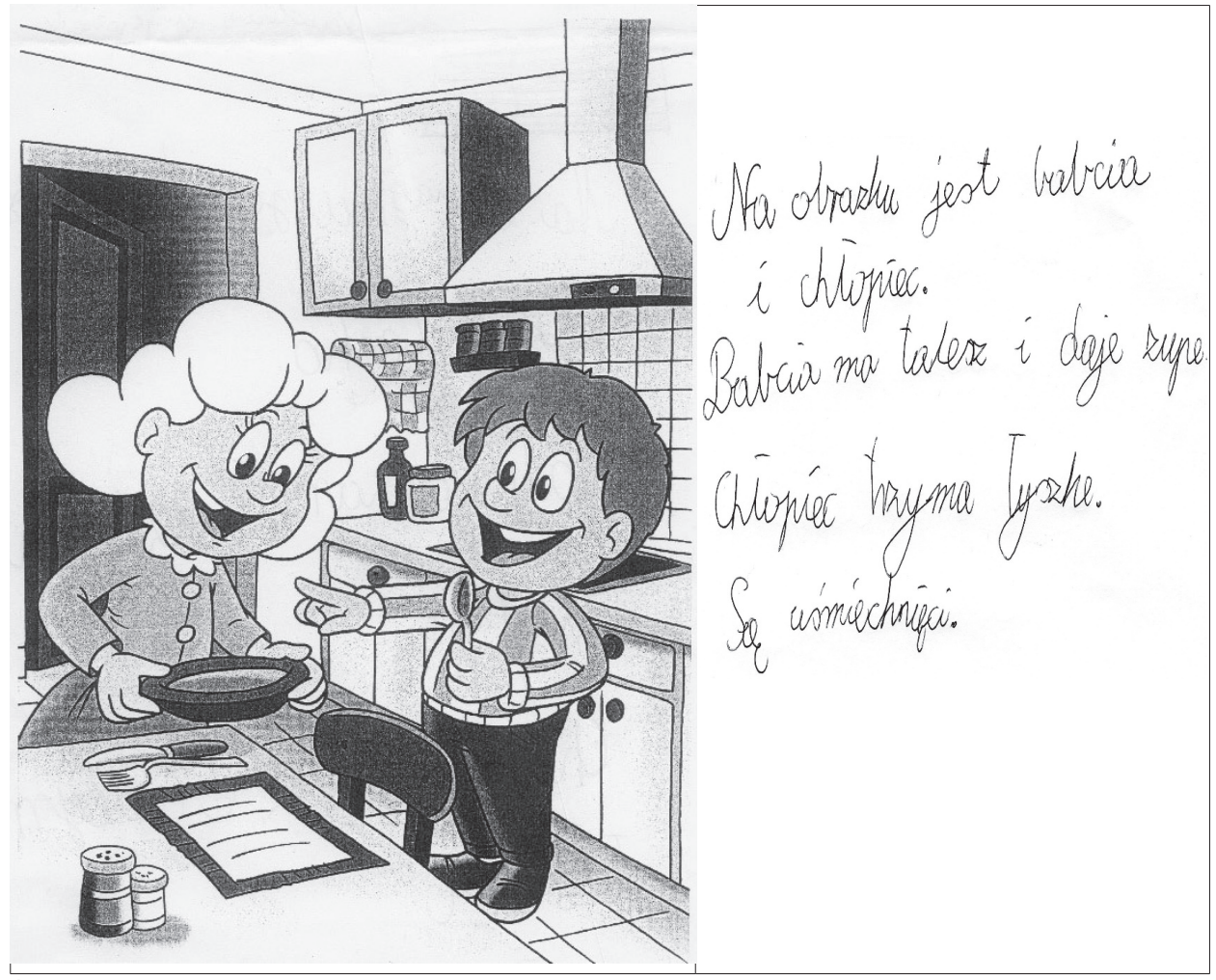

Źródło: Materiały własne.

zują bowiem zasadniczo problemy w pisaniu twórczych tekstów w trzech zakresach, nierzadko współwystępujących z sobą. Po pierwsze nieprawidłowości łączą się z trudnościami związanymi z planowaniem porządku wypowiedzi słownej i osiąganiu poprawności logiczno-stylistycznej; po drugie wiążą się z podwyższoną męczliwością w trakcie wykonywania zadań ruchowych i czasowym ograniczeniem ich wykonania; po trzecie zaś mają związek z deficytami desynchronizacji bodźców wzrokowo-czuciowo-kinestetycznych i wydłużonym czasem ich konsolidacji. Ich następstwem są częste problemy w odbiorze tekstów pisanych w wyniku nieczytelnego i/lub nieprawidłowego ich zapisu, czego przykładem jest fragment listu dwunastoletniego Jakuba: 
Wynik badania: pisanie tekstu twórczego

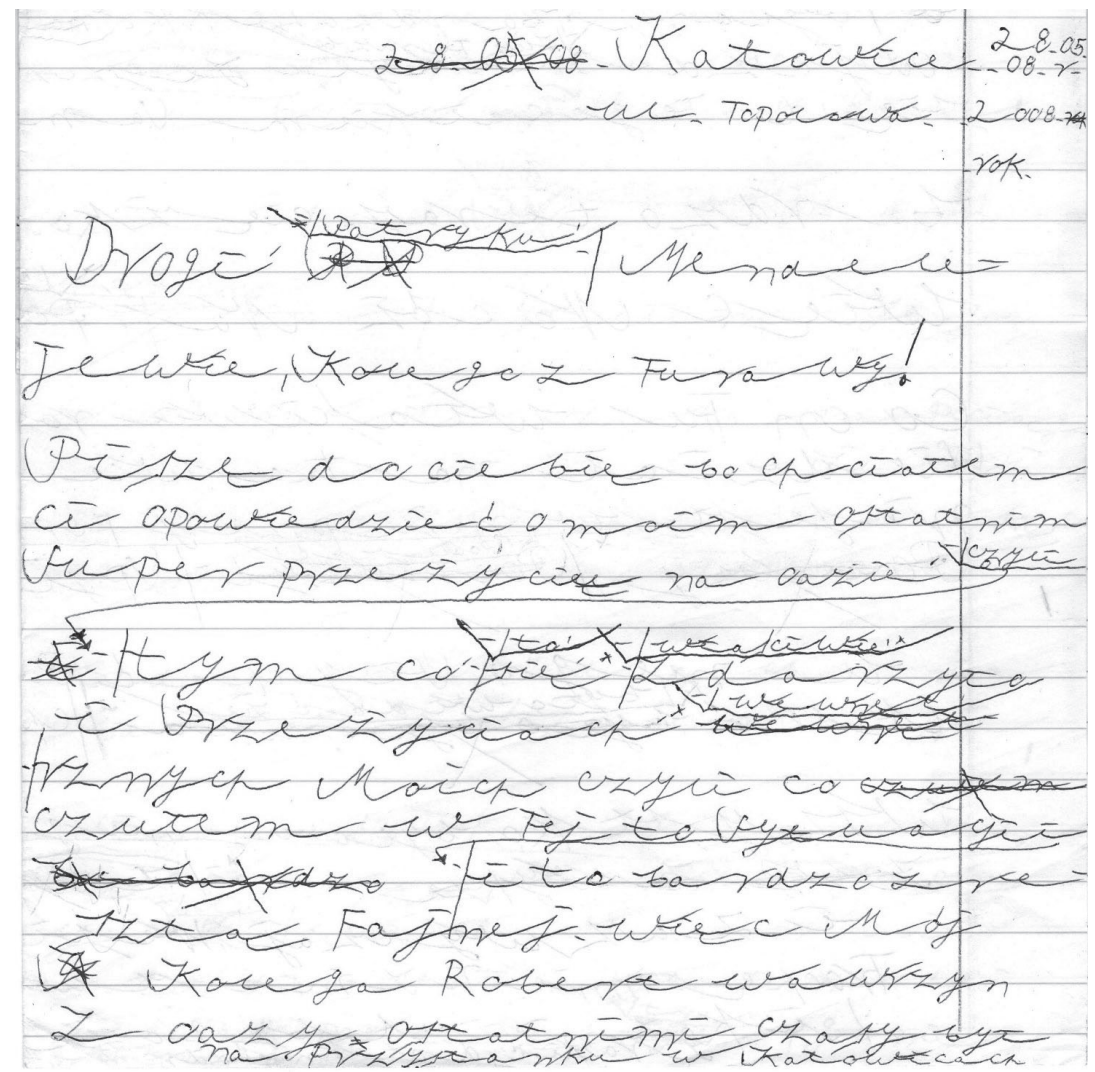

Źródło: Materiały własne.

\section{Wnioski}

Przedstawione analizy pozwalają określić w zarysie trudności uczniów z zaburzeniami rozwoju koordynacji na lekcjach języka polskiego. Dotyczą wybranych aktywności w zakresie edukacji polonistycznej: opanowania techniki czytania i pisania oraz sprawności komunikacyjnej i sprawności językowej w zakresie tworzenia wypowiedzi ustnych i pisemnych.

Na podstawie analizy materiału językowego oraz literatury przedmiotu zostały w artykule przedstawione zagadnienia związane $\mathrm{z}$ funkcjonowaniem uczniów z zaburzeniem rozwoju koordynacji na lekcjach języka polskiego. Omówione 
próby kliniczne wykazały przede wszystkim deficyty w zakresie przetwarzania bodźców wzrokowych oraz słuchowych w ich czasowej desynchronizacji z dotykowo-proprioceptywno-kinestetycznymi modalnościami. Problemy dyspraktyków w przypadku czynności mówienia i czytania wynikają z niedostatecznego opanowania słuchowego lub wzrokowego wzorca wyrazu oraz niedostatecznej pamięci słuchowo-wzrokowo-czuciowo-ruchowej.

Uczniowie wykazują duże trudności ze względu na problem w konsolidacji bodźców czuciowo-kinestetycznych z kontrolą słuchową. Nierzadko stopień poprawności artykulacyjnej głosek ma ścisły związek z zaniżonym poziomem kontroli czuciowo-ruchowej narządów artykulacyjnych i wynikającymi z tego ograniczeniami w zakresie rozwoju percepcji słuchowej.

Nieprawidłowości w zakresie integracji i konsolidacji modalności sensorycznych w programowaniu motorycznym mają również związek z deficytami występującymi w odwzorowywaniu informacji wzrokowych oraz słuchowych i kinestetyczno-proprioceptywnych w próbach: pisania ze słuchu, przepisywania oraz pisania tekstu twórczego. Badanie czynności pisania umożliwia ocenę poziomu funkcjonowania analizatorów: wzrokowego, czuciowego, słuchowego oraz kinestetycznego $\mathrm{w}$ ich wzajemnej konsolidacji celem osiągnięcia poprawnej realizacji programu motorycznego. Ocena prób dotyczących sprawności grafomotorycznej oraz obserwacja umiejętności rozmieszczenia tekstu (na podstawie zebranych prac) wykazała, że badani przejawiają specyficzne zaburzenia wzrokowo-przestrzenne, co może wynikać z deficytów zarówno słuchowych (nieznajomość fonotaktycznego wzorca wyrazu uniemożliwia dzielenie go w zapisie na sylaby i przenoszenie części wyrazów do następnej linijki), jak i kinestetyczno-proprioceptywnych (nierównomierny nacisk narzędzia pisarskiego i wysoka męczliwość ręki stanowią konsekwencje nieprawidłowej pracy mięśni obręczy barkowej). Licznie występujące deformacje liter, które nachodzą na siebie i mają zmieniony obraz (w konsekwencji poszczególne wyrazy nierzadko trudno jest odczytać), mogą być również następstwem niewłaściwej pracy mięśni głębokich szyi i głowy, charakterystycznych dla uczniów z zaburzeniami rozwoju motorycznego. Nieprawidłowa praca tych mięśni może prowadzić do deficytów przedsionkowo-ocznych wyrażających się zaburzeniami ruchomości gałek ocznych. Badani bardzo często zniekształcają zapisywane znaki literowe. Mają trudności z łączeniem liter na poziomie wyrazu. Ich pismo jest nierówne i nieczytelne.

W tabeli 2 zostały uwzględnione jeszcze inne obszary, w obrębie których uczniowie dyspraktyczni mogą wyrażać nieprawidłowości i dysfunkcje. Poza wskazaniem grup trudności, tabela zawiera propozycje rozwiązań metodycznych celem wsparcia funkcjonowania ucznia w dążeniu do jak najlepszego opanowania wiedzy i umiejętności przedmiotowych. Szersze przedstawienie wskazówek, podpowiedzi i porad, w jaki sposób nauczyciel języka polskiego mógłby rozwiązywać opisane trudności, u kogo powinien szukać pomocy, sta- 
nowi bowiem temat na osobny artykuł. Co istotne, w razie zaobserwowania przedstawianych trudności powinno się w pierwszym względzie zwrócić po pomoc do pedagoga szkolnego i logopedy, a następnie skierować ucznia do poradni psychologiczno-pedagogicznej celem wypracowania wspólnych procedur postępowania dydaktycznego.

Tabela 2

\section{Dyspraksja - wtórne strategie w klasie}

\begin{tabular}{|c|c|c|}
\hline Trudność & Objaśnienie & Strategie i przystosowania \\
\hline $\begin{array}{l}\text { Słaba organizacja } \\
\text { pracy; trudności } \\
\text { w wykonywaniu } \\
\text { poleceń i instruk- } \\
\text { cji }\end{array}$ & $\begin{array}{l}\text { słaba integracja wzrokowo-prio- } \\
\text { prioceptywno-kinestetyczna (nie- } \\
\text { rzadko: słaba integracja wzroko- } \\
\text { wo-słuchowo-prioprioceptywno- } \\
\text {-kinestetyczna); słabe umiejętności } \\
\text { planowania motorycznego (niskie } \\
\text { tempo pracy; problem z organiza- } \\
\text { cją czasu pracy); niskie umiejęt- } \\
\text { ności w zakresie planowania prze- } \\
\text { strzennego; słaba interioryzacja } \\
\text { i eksterioryzacja procesów uczenia }\end{array}$ & $\begin{array}{l}\text { przygotowywać plan pracy (ze } \\
\text { wskazaniem porządku czasu pra- } \\
\text { cy); określać kolejne etapy wyko- } \\
\text { nywania czynności (przekaz wer- } \\
\text { balno-ikoniczny); stosować pokazy, } \\
\text { wizualizacje }\end{array}$ \\
\hline $\begin{array}{l}\text { Deterioracja my- } \\
\text { ślenia i trudności } \\
\text { w rozwiązywaniu } \\
\text { zadań różnego ty- } \\
\text { pu }\end{array}$ & $\begin{array}{l}\text { trudności w uporządkowaniu myśli } \\
\text { (skróty myślowe; liczne dygresje); } \\
\text { kłopoty z koncentracją uwagi; wy- } \\
\text { soka przerzutność uwagi; trudności } \\
\text { w planowaniu oraz organizacji pra- } \\
\text { cy; niski poziom myślenia abstrak- } \\
\text { cyjnego }\end{array}$ & $\begin{array}{l}\text { przygotować szablony/wzory z ty- } \\
\text { tułami, które pomogą osobie roz- } \\
\text { wiązać zadanie; przygotować plan } \\
\text { postępowania (wskazać etapy dzia- } \\
\text { łania); określać kolejne etapy wy- } \\
\text { konywania czynności, np. słowa } \\
\text { kluczowe }\end{array}$ \\
\hline $\begin{array}{l}\text { Obniżona spraw- } \\
\text { ność interakcyjna; } \\
\text { trudności w poro- } \\
\text { zumiewaniu się } \\
\text { z rówieśnikami }\end{array}$ & $\begin{array}{l}\text { trudności w budowaniu komunika- } \\
\text { tów werbalnych (sposób wypowia- } \\
\text { dania się nieadekwatny do języka } \\
\text { grupy rówieśniczej) i niewerbal- } \\
\text { nych (nierzadko zachowania nie- } \\
\text { adekwatne do sytuacji); dystans } \\
\text { wobec rozmówców; trudności w ro- } \\
\text { zumieniu humoru i sarkazmu }\end{array}$ & $\begin{array}{l}\text { trening w zakresie umiejętności } \\
\text { społecznych; chwalić indywidual- } \\
\text { ność; dzielić się przykładami do- } \\
\text { brej komunikacji i dobrych prak- } \\
\text { tyk; zachęcać do uczestniczenia } \\
\text { w zajęciach, które odpowiadają } \\
\text { zainteresowaniom uczniów, takich, } \\
\text { jak lekcje szachów lub gry na bęb- } \\
\text { nie }\end{array}$ \\
\hline $\begin{array}{l}\text { Obniżona umie- } \\
\text { jętność tworzenia } \\
\text { wykresów, sche- } \\
\text { matów, tabel i ich } \\
\text { wypełniania }\end{array}$ & $\begin{array}{l}\text { słaba integracja wzrokowo-prio- } \\
\text { prioceptywno-kinestetyczna; ni- } \\
\text { skie umiejętności w zakresie plano- } \\
\text { wania przestrzennego }\end{array}$ & $\begin{array}{l}\text { przygotowywać szablony wykre- } \\
\text { sów, tabel, schematów celem nauki } \\
\text { ich wypełniania; określać kolejne } \\
\text { etapy wykonywania czynności } \\
\text { (przekaz werbalno-ikoniczny); sto- } \\
\text { sować przykłady do odwzorowy- } \\
\text { wania bądź uzupełniania }\end{array}$ \\
\hline
\end{tabular}

Źródło: Opracowanie własne na podstawie: Dyspraxia — Secondary Clasroom Strategies. https://dyspraxiafoundation. org.uk/wp-content/uploads/2013/10/Secondary_Classroom_Strategies.pdf [data dostępu: 21.10.2012]. 


\section{Zakończenie}

Wyniki odnotowane w badaniach zaburzeń neurorozwojowych wykazują związek funkcji motorycznych oraz wykonawczych, w których następstwie ujawniają się trudności w zakresie artykulacji, w opanowaniu techniki czytania i techniki pisania, w planowaniu i koordynacji działania, wraz z towarzyszącymi im zaburzeniami uwagi.

Jak podkreśla Anna J. Ayres, twórczyni metody integracji sensorycznej, która na podstawie obserwacji klinicznej swoich pacjentów skierowała uwagę na istotność poziomu zaawansowania umiejętności motorycznych u dzieci i młodzieży:

[...] chociaż objawy dyspraksji mają charakter ruchowy, jest ona czymś więcej niż tylko zaburzeniem motorycznym ${ }^{32}$.

Poziom złożoności zachowań ruchowych odzwierciedla stan integracji (dojrzałości) pomiędzy postrzeganymi bodźcami płynącymi z modalności czuciowych a stopniem zaawansowania ich koordynacji na wszystkich poziomach układu nerwowego. W nieprawidłowości przetwarzania informacji sensorycznych dochodzi do zmiany sił połączeń między komórkami nerwowymi. Powstała wówczas różnica $\mathrm{w}$ zakresach przetwarzanych informacji sensorycznych uniemożliwia równoczesne scalanie bodźców płynących z różnych modalności w następstwie czego dochodzi do zachwiania równowagi międzyukładowej, gdyż ,somatosensoryczne informacje zwrotne stanowią krytyczny element kontroli motorycznej [..." "33. Problemy motoryczne ucznia z dyspraksją obejmują szereg sprawności realizacyjnych, w tym opanowanie techniki czytania i pisania oraz sprawności komunikacyjnej i sprawności językowej w zakresie tworzenia wypowiedzi ustnych i pisemnych.

\section{Bibliografia}

Adapted Physical Activity Quarterly. Ed. S.E. Henderson. Special Issue: „Developmental. Coordination Disorder" 1994, No. 11.

Affolter F.: Spostrzeganie, rzeczywistość, język. Tłum. T. Duliński. Warszawa 1997.

${ }^{32}$ A.J. Ayres: Dziecko a integracja sensoryczna. Tłum. J. Okuniewski. Gdańsk 2015, s. 190.

${ }^{33}$ G. Hickok: Mit neuronów lustrzanych..., s. 223. 
Ayres A.J.: Dziecko a integracja sensoryczna. Tłum. J. Okuniewski. Gdańsk 2015.

Barnett A.L., Kooistra L., Henders on S.E.: „Clumsiness” as syndrome and symptom. „Human Movement Science" 1998, Vol. 17, Issues 4-5.

Beek P.J. \& van Wieringen P.C.: Human Movement Science. Special Issue: „Developmental Coordination Disorder: Diagnosis, description, processes and treatment” 2001, No. 20.

Cairney J.A. et al.: Developmental coordination disorder and overweight and obesity in children aged 9-14 y. „International Journal of Obesity” 2005, No. 29.

Coleman R. et al.: Kinaesthetic acuity in preprimary children at risk of developmental coordination disorder. „Australian Educational and Developmental Psychologist” 1997, No. 14.

Czabański B.: Kształcenie psychomotoryczne. Wrocław 2000.

Geuze R.H., Kalverboer A.F.: Inconsistency and adaptation in timing of clumsy children. „Journal of Human Movement Studies" 1987, Vol. 13, Issue 8.

Geuze R.H., Kalverboer A.F.: Tapping a rhythm: A problem of timing for children who are clumsy and dyslexic. „Adapted Physical Activity Quarterly” 1994, Vol. 11, Issue 2.

Górniewicz E.: Pedagogiczna diagnoza specyficznych trudności w czytaniu i pisaniu. Toruń 1998.

Hickok G.: Mit neuronów lustrzanych. Rzetelna neuronauka komunikacji i poznania. Tłum. K. Cipora, A. Machniak. Kraków 2016.

Klasyfikacja zaburzeń psychicznych i zaburzeń zachowania w ICD-10. Opisy kliniczne i wskazówki diagnostyczne. Red. przekł. S. Płużyński, J. W ciórka. Kraków-Warszawa 2007.

Laszlo J.I. et al.: Clumsiness or perceptuo-motor dysfunction?. In: Cognition and action in skilled behaviour. Eds. A.M. Colley, J.R. Beech. Amsterdam 1988.

Laszlo J.I. et al.: Process oriented assessment and treatment of children with developmental coordination disorder. „Corpus Psyche et Societas” 1996, No. 3.

Lorenc Z., Wróbel T.: Nauka czytania i pisania. W: Praca nauczyciela i ucznia w klasach 1-3. Red. M. Lelonek, T. Wróbel. Warszawa 1990.

Lundy-Ekman L. et al.: Timing and force control deficits in clumsy children. „Journal of Cognitive Neuroscience" 1991, Vol. 3, No. 4.

Matyja M.: Neurorozwojowa analiza wad postawy ciała u dzieci i młodzieży. Katowice 2012.

Mass V.F.: Uczenie się przez zmysty. Wprowadzenie do teorii integracji sensorycznej. Tłum. E. Grzybowska, Z. Przyrowski, M. Ślifirska. Warszawa 1998.

Mon-Williams M.: Ophthalmic factors in developmental coordination disorder. „Adapted Physical Activity Quarterly" 1994, Vol. 11, Issue 2.

Mon-Williams M. et al.: Visual-proprioceptive mapping in developmental coordination disorder. „Developmental Medicine and Child Neurology” 1999, Vol. 41, Issue 4.

Parker H.E. et al.: Are motor timing problems subgroup specific in children with developmental coordination disorder? ,Australian Educational and Development Psychologist” 1997, Vol 14, Issue 1.

Piek J.P., Skinner R.A.: Timing and force control during a sequential tapping task in children with and without motor coordination problems. ,Journal of the International Neuropsychology Society" 1999, Vol. 5, Issue 4.

Piek J.P. et al.: Motor coordination and kinaesthesis in boys with attention deficit-hyperactivity disorder. „Developmental Medicine and Child Neurology” 1999, Vol. 41, Issue 3.

Piotrowska M., Szymańska M.: Nowe już w szkole. Warszawa 2009.

Platt G.: Pokonać dyspraksję. Prosty program ćwiczeń poprawiających umiejętności ruchowe w domu $i$ w szkole. Tłum. P. Sørensen. Gdańsk 2015.

Pöhlmann R.: Motorisches Lernen: psychomotorische Grundlagen der Handlungsregulation sowie Lernprozessgestaltung im Sport. Sportwissenschaft für die Praxis (t. I). Berlin 1986.

Przybyla O.: Motoryczne zdolności koordynacyjne w świetle badań nad mowa. W: Metodologia badań logopedycznych z perspektywy teorii i praktyki. Gdańsk 2015. 
Przybyla O.: Studium przypadku dziecka z zaburzeniami motorycznymi o podtożu sensorycznym. „Logopedia Silesiana” 2016, t. 5.

Przybyla O.: Zaburzenie rozwoju koordynacji - dyspraksja. Przegląd badań. „Logopedia Silesiana" 2016, t. 5.

Raynor A.J.: Strength, power, and coactivation in children with developmental coordination disorder. „Developmental Medicine and Child Neurology” 2001, Vol. 43, Issue 10.

Sadowski B.: Biologiczne mechanizmy zachowania się ludzi i zwierząt. Warszawa 2012.

Sigmundsson H.: Inter-modal matching and bi-manual co-ordination in children with hand-eye co-ordination problems. „Nordisk Fysioterapi” 1999, No. 3.

Sigmundsson H. et al.: Inter- and intra-sensory modality matching in children with hand-eye co-ordination problems. „Experimental Brain Research” 1997, Vol. 114, Issue 3.

Volman M.J.M., Geuze R.H.: Stability of rhythmic finger movements in children with a Developmental Coordination Disorder. „Motor Control” 1998, Vol. 2, Issue 1.

Volman M.J.M., Geuze R.H.: Relative phase stability of bimanual and visuomanual rhythmic coordination patterns in children with a developmental coordination disorder. „Human Movement Science" 1998, No. 17.

Wann J.P., Mon-Williams M., Rushton K.: Postural control and co-ordination disorders: The swinging room revisited. „Human Movement Science” 1998, Vol. 17, Issues 4-5.

Williams H.G. et al.: Timing and motor control in clumsy children. „Journal of Motor Behavior” 1992, Vol. 24, Issue 2.

Williams H.G., Castro A.: Timing and force characteristics of muscle activity: Postural control in children with and without developmental coordination disorders. „Australian Educational and Developmental Psychologist" 1997, Vol. 14, Issue 1.

Williams H.G., Woollacott M.: Characteristics of neuromuscular responses underlying posture control in clumsy children. „Motor Development: Research and Reviews” 1997, Vol. 1.

Wróbel T.: Pismo i pisanie w nauczaniu początkowym. Warszawa 1985.

\section{Źródła internetowe}

Dyspraxia - Secondary Clasroom Strategies. https://dyspraxiafoundation.org.uk/wp content/uploa ds/2013/10/Secondary_Classroom_Strategies.pdf. 